ELORE (ISSN 1456-3010), vol. 19 - 1/2012.

Julkaisija: Suomen Kansantietouden Tutkijain Seura ry.

[http://www.elore.fi/arkisto/1_12/hovi.pdf]

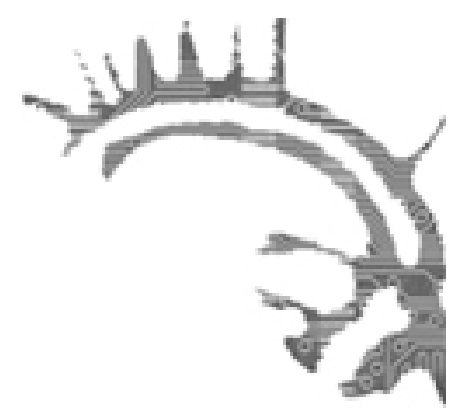

\title{
KIRJA-ARVIO
}

\section{PERINTEET, FANATISMIT JA VAPAAT VALINNAT}

SIHVOLA, JUHA 2011: Maailmankansalaisen uskonto. Helsinki: Otava. 399 sivua.

\section{Tuija Hovi}

Sekä tieteellinen että populaari keskustelu uskonnosta - puolesta, vastaan ja siltä väliltä - on virinnyt varsin aktiiviseksi maallistuneiksi luokitelluissa länsimaissa kuluvan vuosikymmenen aikana. Myös suomalaisessa tiedeyhteisössä niin uskovat kuin ateistitkin ovat viime vuosina astuneet "kaapeistaan" perustellakseen kantojaan kirjallisesti ja määritelläkseen asemaansa suhteessa uskontoon. Uuden keskustelun tarpeen syyt ovat varmasti moninaiset. Niiden voi arvailla liittyvän niin kansainvälisen terrorismin uskontokytköksistä kotimaisten moraalikysymysten ja kirkon aseman pohtimiseenkin, kuin myös vähemmistöryhmien oikeuksiin ja globalisaatioon. Filosofi-historioitsija Juha Sihvola on kantanut kortensa kekoon Maailmankansalaisen uskonto -teoksellaan, joka avaa monia ajankohtaisia kysymyksiä valottaen niiden historiallisia taustoja sekä asetelmia nykypäivän yhteiskunnissa.

Teos ei ole lähtökohtaisesti perinnetieteellinen teos, vaikka uskontoperinteet aiheena ovatkin. Ennen kaikkea se on filosofinen sekä yhteiskunta- ja historiatieteellinen tietokirja, jonka punaisena lankana on suvaitsevaisuuden edistäminen ja kaiken suuntaisista ääriaineksista kaukana pysyminen. Sihvola tarjoaa missionsa ohella avartavia näkökulmia maailmanuskontojen monimuotoisuuteen sekä sisäisiin ristiriitoihin ja suhtautuu uskontoon perinteenä, johon olennaisesti kuuluu vaihtelu. Viiteen laajaan lukuun temaattisesti jäsennelty Maailmankansalaisen uskonto on pieteetillä rakennettu kokonaisuus ja joka suhteessa lukijaystävällinen tietokirja. 
Tuija Hovi: Perinteet, fanatismit ja vapaat valinnat

\section{USKONTOKRITIIKIN KRITIIKKI JA MORAALIN JUURET}

Kirja alkaa filosofisesti moniulotteisen uskontokritiikin pohdinnalla sekä moraalin, etiikan ja uskonnon kosketuspintojen tarkastelulla. Sihvolan puheenvuoron perusvire paljastuu hänen alkajaisiksi esittämässään kysymyksessä "Miksi uskonto on tärkeää?" Vastatakseen kysymykseensä perusteellisesti Sihvola aloittaa punnitsemalla Nietzschen klassista uskontokritiikkiä, johon muut filosofiset uskontokritiikit peilautuvat. Sihvolaa ne eivät vakuuta, sillä ne eivät hänen mukaansa ota huomioon uskontojen eri muotoja vaan suhtautuvat niihin kaikkiin miltei kuin uskonnolliseen fundamentalismiin. Erityisesti uusateistit saavat kirjoittajalta tässä suhteessa huonon arvosanan. Eri näkökulmat ja painotukset sävyttävät toki myös ateismeja sekä agnostismeja, siis kieltäviä, kriittisiä tai varauksellisia suhtautumistapoja teistisiä uskontoja kohtaan. Näitä erilaisia positioita Sihvola erittelee ja yhdistää niiden äärimuodot samaan fanatismin perinteeseen kuin sen, mitä ne kritisoivat.

Kirjassa saa paljon tilaa myös pohdinta uskonnon ja moraalin kytköksistä sekä uskontoneutraalin tai "luonnollisen" moraalin perusteista. Sihvola piirtää kuvaa uskonnollisten eetosten synnystä ja pohtii moraalisten vaateiden oikeutusta monelta kannalta sekä eri osapuolten näkökulmasta. Moraalikysymyksissä tiivistyvät myös uskonnon kulttuuriset tehtävät, kun myytit, legendat ja kaikkinainen uskonnollinen kansanperinne kertomuksineen ja kyseenalaistamattomine tapoineen juurruttaa mieleen käsitykset oikeasta ja väärästä usein riippumatta siitä, onko vastaanottaja uskonnollisesti aktiivinen vai ei. Mielenkiintoisia esimerkkejähän ovat olleet vaikkapa homoliittokeskustelut, joissa viimeisenä valttina on usein vedetty esiin historiallisesta ja tekstuaalisesta kontekstistaan irrotetut Raamatun lauseet siitä huolimatta, että valtaosalla väestöstä on käytännössä hyvin vähän kosketuspintaa itse teemaan tai jollakin tavoin uskonnollisesti orientoituneeseen elämäntapaan. Sihvola johdattaa lukijaa ymmärtämään protestanttisen kristinuskon kaksijakoisuutta luterilaisen ja kalvinistisen tradition moraalisten velvoitteiden muodostumisen historialla. Oman tarkastelunsa saavat kapitalismi, globaali markkinatalous, seksuaalietiikka ja suhtautuminen väkivaltaan, ympäristöön ja tulevaisuuteen.

\section{VAPAUS, PERHEYHTÄLÄISYYS, TASA-ARVO}

Uskonnonvapaus ei ole itsestäänselvyys eikä universaali etuoikeus, mutta ei myöskään mikään uusi asia sinänsä. Sihvola kartoittaa eurooppalaista suvaitsevaisuuden ja suvaitsemattomuuden uskontohistoriaa antiikin Kreikasta alkaen. Suvaitsevaisuus vapaaehtoisena sietämisenä ja siivona rinnakkaiselona erimielisyyksistä huolimatta on Sihvolan mukaan nimenomaan länsimaisen kristillisen teologian tuote - samoin kuin äärimmäinen suvaitsemattomuus. Kerettiläisyyden käsite juurtui jo apostolien ajoilta lähtien syvälle kristillisyyteen ja vahvistui entisestään keskiajan katolisen kirkon kamppaillessa protestiliikkeitä vastaan. Erilaiset puhdistus- ja uudistusliikkeet ovat paitsi rajanneet pyhänä pidettyjen traditioiden tulkintaa, myös samalla laajentaneet 
Tuija Hovi: Perinteet, fanatismit ja vapaat valinnat

variaatioskaalaa yhden uskonnon sisällä siitä huolimatta, että ne ovat pääsääntöisesti määritelleet itsensä "paluuksi alkuperäiseen". Eivätkä reformiliikkeet suinkaan ole vain kristinuskoon kuuluva piirre, vaan myös esimerkiksi islamia ovat monet uudistusliikkeet ja lahkot pyrkineet muokkaamaan.

Historiakatsauksesta suvaitsevaisuuden ja uskonnonvapauskysymysten tarkasteluun modernissa länsimaisessa yhteiskunnassa siirtyessään Sihvola nostaa keskeisiksi kysymyksiksi omantunnon vapauden, vakaumuksen kunnioittamisen ja sananvapauden. Hän pohtii suvaitsevaisuutta suhteessa nykyiseen uskontokeskusteluun erityisesti kahden filosofin, John Rawlsin ja Martha Nussbaumin kirjoitusten valossa. Sihvola ei pelkästään analysoi vaihtoehtoja vaan ottaa myös kantaa. Hän päätyy varauksellisesti puolustamaan poliittista liberalismia ja perustelee: "Jos kansalaiskasvatus on onnistuneesti järjestetty ja jos se edistää itsenäistä ajattelua, erilaisuuden kunnioitusta ja myötätuntoista solidaarisuutta heikkoja ja haavoittuvia kohtaan, poliittinen konsensus tasa-arvon puolesta voi syntyä.” (s. 268.) Pohdinta kansalaiskasvatuksesta jatkuu uskonnon kouluopetuksesta ja kristillisen teologian paikasta yliopistollisena oppiaineena.

\section{PolittTisten KonflikTiEn USKonNot}

Uskontojen sisäinen moniarvoisuus ja ristiriitaisuus konkretisoituvat ennen kaikkea konfliktitilanteissa. Liberalismin ja fundamentalismin perinteitä on suorastaan vaikea ymmärtää saman emotradition piiriin kuluviksi. Pitkäaikaisten ja veristen poliittisten konfliktien ytimessä nähdään usein uskonto. Sihvola pohtii liberaalin islamin mahdollisuuksia globalisaation hermostuttaman islamistisen fundamentalistipropagandan rinnalla ja kertaa monin tavoin sivistävällä otteella historiaa, joka kiinnittyy hindunationalismiin ja sionismiin, joiden arkkivihollisena ja olemassaolon motiivina on islam.

Kirjoittaja muistuttaa useampaankin otteeseen uskontojen monimuotoisuudesta, siitä että saman uskontotradition kenttään sisältyy sekä rakentavia että tuhoavia muotoja kuin myös sisäisiä arvoasetelmia. Kuvaavaa on esimerkiksi eripuolilta maailmaa emigroituneiden juutalaisten keskinäinen hierarkia Israelissa; niin kutsutusta paluulaista huolimatta Israelin kansalaisuuden saaminen ei ole maahan muuttavalle juutalaiselle itsestäänselvyys. Merkityksellisiä ovat myös eri uskontojen keskinäiset suhteet. Sihvola osoittaa historiakatsauksillaan, että uskonnolliseen fundamentalismiin vannovissa väkivaltaisissa ääriliikkeissä on kysymys pikemminkin poliittisia etuja ajavasta nationalistisesta kansakunta-ajattelusta kuin elämäntavan ja hengellisyyden kysymyksistä. Sionisminkin alkuhistoria sijoittuu 1800-luvun kansallisromantiikan kukoistukseen Euroopassa.

\section{SIVISTYKSEN PUHEENVUORO}

Juha Sihvolan teos on paitsi monipuolinen ja avartava tietokirja myös kantaaottava manifesti tiedon ja oman ajattelun puolesta populismia ja fanaattisuutta vastaan. Se 
Tuija Hovi: Perinteet, fanatismit ja vapaat valinnat

on niin ikään puheenvuoro kosmopoliitin uskonnon puolesta, johon kuuluu suvaitsevaisuus, sivistys ja kiihkoton rinnakkaisuus. Sihvolan ohjelmallisuuteen kuuluu myös avoin ääriainesvastaisuus, mutta myös sen perustelu, miksi kaikkinainen fanatismi, niin uskonnon puolesta kuin sitä vastaankin on tuhoisaa. Viestin voi ymmärtää siten, että usein parjattu "tapauskonnollisuus" on ihan suotavaa, sillä Sihvolan maailmassa juuri se on fanatismilta suojaava ja turvallisin vaihtoehto.

Uskonto on sellainen kulttuurielementti, joka rakentaa todellisuutta myös sekularisoituneessa yhteiskunnassa, hyväksyipä sen tai ei. Se vaatii myös kannanottoa vähintään niissä tilanteissa, joissa uskonnolla perustellaan omaa moraalia haastavia tekoja. Tiukasti puolensa valinneille Maailmankansalaisen uskonto ei ole helppo kirja, mutta sitäkin suositeltavampi.

Filosofian tohtori Tuija Hovi on Suomen Akatemian tutkijatohtori Åbo Akademin uskontotieteen oppiaineessa. 